\title{
Religious Education at Crossroads in the UK: Muslim Responses to Registration, Regulation and Inspection
}

\author{
Imran Mogra - AUTHOR
}

\begin{abstract}
Madrasah education is the bedrock of Muslim communities the world over. They are established, in essence, for the religious, spiritual, moral and social development of Muslim children. Recently, the Department for Education in the UK issued a call for evidence for requiring certain out-of-school settings to be registered, regulated and inspected. Responses to this proposal have been varied, some welcoming it whilst others expressed serious concerns. This paper explores the trends in the responses made to these proposal by three Muslim organisations. It begins by providing a nuanced understanding of the terms maktab and madrasah and shows that the call is not a new one at all. Thereafter, the worry of many politicians, educators and faith groups are considered. The findings reveal that Muslim organisations support and welcome measures to strengthen the safeguarding and well-being of children. However, a summative analysis of their responses reveals that they have serious concerns about many aspects of the proposal and the context within which it has been conceived.
\end{abstract}

\section{Introduction}

In recent years, educational settings have become vehicles for the Government to tackle issues related to 'extremism' and 'terrorism'. This includes nurseries, schools and higher education institutions. In October 2015, the then British Prime Minister David Cameron invited his party to end discrimination, fight for real equality, tackle the causes of poverty and confront 'extremism'.

It is in this context that he mentioned religious educational settings. He had announced: "If an institution [was] teaching children intensively, then whatever its religion, we will, like any other school, make it register so it can be inspected." "He stressed that if anyone were found to be teaching intolerance, they would face closure. He then called for the regulation of supplementary schools and said that madrasahs, Sunday schools, yeshivas (Jewish schools) and other institutions teaching children intensively would be registered with the Department of Education (thereafter DfE) and subject to inspection.

Within a fortnight, the Counter-Extremism Strategy (CES) was published on 19 October $2015 .{ }^{3}$ The most prominent feature of the CES in countering extremist ideology is that of strengthening institutions -specifically educational ones. The strategy recorded, in regards to supplementary schools and tuition centres that the Government values and supports the role these organisations play in society. However, it also recognised that there is little regulation or oversight of these settings and limited information on the practices within them. ${ }^{4}$ Thus, this proposal becomes part of the Government strategy to combat 'radicalisation' and, in so doing, 
it justifies the introduction of a new system by the DfE to enable intervention in supplementary schools which teach children intensively. This intervention, it stated, would apply if there were "concerns about the safety or welfare of the children attending them, including from extremism. This will provide for the registration of settings so that they can be inspected and will introduce appropriate sanctions to protect children." In other words, the Government seems to have merged two policies to bear on matters of faith development and nurture. The CES stressed that these settings will be those which teach children 'intensively' and where 'concerns' are raised.

Subsequently, the DfE launched its call for evidence to inform the development of the Government's proposal for requiring certain [my emphasis] out-of-school education settings to register and be subject to risk-based inspections. ${ }^{6}$ The call had opened on 26th November 2015 and, with a short deadline, closed on 11 January 2016.

Following the publication of the call for evidence, other criteria became evident during a debate in Westminster Hall on Wednesday 20 January 2016. In a lengthy deliberation covering a very wide range of issues and concerns, Nick Gibb, now the Minister of State for School Standards and Minister for Equalities, had confirmed that "the Government are not proposing to regulate settings teaching children for a short period every week, such as Sunday schools or the scouts, nor will it apply to one-off residential activities, such as a week-long summer camp." It was, however, "looking specifically at places where children receive intensive education outside schools, where they could typically be spending more than six to eight hours a week." He also confirmed that "Sunday schools will not be under any requirement to teach any other religions."

Thereafter, Nicky Morgan, the then Secretary of State for Education, responding to a question in Parliament about the mixed messages issued by the then Prime Minister and Ofsted regarding concerns held by many churches and youth organisations of being subjected to nationwide registration schemes, clarified, "It is right that we are asking the question about registration of out-of-school settings and therefore inspection, but the Prime Minister and I are clear that that is not to apply to organisations such as Sunday schools. Indeed, I am a Sunday school and Bible camp teacher myself."

This study explores the trends in the responses made to this proposal by three Muslim organisations. As the Muslim community stands at yet another crossroad in the development of education, it is not only essential to reflect on what has been proposed thus far, but also, to identify the gaps in the knowledge and understanding of the issues at stake vis a vis, the aspirations and anxieties of providing religious nurture in the context of the current political agenda. Therefore, at first, a brief background will provide a nuanced understanding of the terms maktab (pl. makātib) and madrasah (pl. madāris) and their engagement with initiatives related to civic and citizenship education, followed by a comment on the monitoring of madāris (thereafter madrasahs) as a tool to evaluate the reintroduction of the agenda of regulating these settings. Thereafter, general responses from politicians, educational groups and various communities are presented to demonstrate the diverse nature of concerns and the far-reaching impact that these proposals might have. The key elements from the proposals are then highlighted. Before presenting a summative analysis of the responses by the Muslim organisations, a brief outline about these organisations is provided. Finally, a discussion is presented focussing on some of the main issues. 


\section{Background}

The subject of improving the quality of the management of madrasahs and their associated classroom practices has been an area of discussion among researchers, practitioners and members of the community for some time. ${ }^{9}$ However, the relatively recent concerns are of a different kind. They feature within the context of faith schools, 'extremism' and 'terrorism'. ${ }^{10}$

The term 'madrassa' has become a catchall by many of its users especially those in the media, politicians and some academics to refer to institutes delivering a curriculum based on the teachings of Islam -regardless of its stage and age. In the UK context, full time independent faith schools are not the same as supplementary schools. The former are required to register with the DfE which involves meeting regulatory standards including the quality of education provided; welfare, health and safety of pupils; suitability of proprietors and staff; and school premises. Independent schools of all faiths are also subject to routine inspections. ${ }^{11}$ This category of Muslim independent schools teach, in addition to the requirements of a broad and balanced curriculum, Islamic studies, possibly Arabic, and/or a community language, all within an Islamic faith based ethos. ${ }^{12}$ Some supporters of such full-time faith schools point to their academic results, their potential to promote diversity and tolerance, good discipline and religious ethos, among other reasons. ${ }^{13}$ On the other hand, there remains considerable public and media suspicion about the social impacts that these independent faith schools may be having, with critics focusing on the ways in which they may be segregating young people along religious and ethnic lines. ${ }^{14}$

However, most supplementary schools, i.e., madrasahs operate independently and are established by members of the Muslim community for Muslim children. They are characterised as supplementary, community or complementary schools as they are self-help initiatives set up to deliver Islamic education in order to preserve religious, spiritual, cultural and linguistic identities. They tend to operate from local mosques, primarily with the purpose of teaching the Qur'ān and Islam, although others provide tuition to support their school work. Their finance is mainly generated through fees, funding and, mostly, donations from the local community. ${ }^{15}$ Some are organised in private homes and the duration varies. Some operate on five days a week for one or two hours after school. Others provide sessions on weekends in schools and community centres. ${ }^{16}$

On the other hand, a Dār ul 'ulūm is also an independent educational institute which offers learning in Islamic subjects. However, this is at an advanced level. The subjects studied include Arabic language, exegesis of the Qur'ān, Hadīth Studies and jurisprudence, among others. Often, in some of them this curriculum is based on a modified syllabus known as dars$e$-nizāmi. These Dār ul 'ulūms are also subject to regular inspections by the Office for Standards in Education (Ofsted) and have to meet the required regulations of various kinds. ${ }^{17}$ The madrasahs, on the other hand, being established on a voluntary basis and functioning in a parttime capacity to provide, ostensibly, faith formation, nurture and instruction in Islam are not subject, like those of other faiths, to the same oversight as these full time educational institutions. The Dār ul 'ulūms are also referred to as madrasahs. Unless otherwise stated, in this paper the term supplementary schools refers to madrasahs.

These madrasahs have come under additional scrutiny for the role that they may be suspected to play in facilitating the radicalisation of young Muslims towards violent extremism. ${ }^{18}$ Generally, these fears, are not based on rigorous research but rather on 
intermittent reporting and speculation in the media. Consequently, this leads to a poor understanding amongst policymakers and the wider public. Thus, Cherti, Glennie and Bradley noted a need for better understanding of Muslim supplementary education in the UK. ${ }^{19}$ Importantly, in their research, they reported an absence of strong evidence linking madrasahs to the radicalisation of young people in the UK.

It is estimated that there are approximately 2,000 madrasahs in the UK known to local councils and where staff have undergone the proper checks and procedures to allow them to work with children in a safe environment. ${ }^{20}$ For example, a number of reports have been commissioned to improve the understanding of supplementary education in general, and Muslim schooling in particular. ${ }^{21}$ Governments have also funded various initiatives that seek to raise the attainment of Muslim pupils in both mainstream and supplementary schools, to build bridges between madrasahs and other local schools and organisations, and to promote better practice within madrasahs. ${ }^{22}$ There are many madrasahs who are members of The National Resource Centre for Supplementary Education (NRCSE) and have gained awards at various levels based on their Quality Framework and Code of Practice mentioned hereunder. Moreover, there have been high profile projects involving citizenship education in madrasahs using the ICE (Islam and Citizen Project) in many parts of the country for many years. ${ }^{23}$ Thus, the creation of an impression of madrasahs operating in 'secret' seem exaggerated.

\section{Monitoring Madrasahs}

The idea that there was going to be a kind of regulatory mechanism for monitoring Muslim educational institutes has been expected for some time. Plans for the introduction of a voluntary code of conduct for religious supplementary schools had been set out by the Taskforce on Tackling Radicalisation. ${ }^{24}$ To widen the protection of school children further, the Task Force had agreed to improve oversight of religious supplementary schools. The code of practice intended that schools would implement robust policies to protect children and young people from harm, including exposure to intolerant or 'extremist' views. Consequently, it had hoped that parents would be enabled to make informed decisions about the right choice of supplementary school for their children.

The then Home Secretary, Theresa May, was not convinced that a voluntary code would be sufficient. In her letter to Michael Gove (former Secretary of State for Education), she was resolute that a mandatory code, rather than a voluntary one, should be considered. ${ }^{25}$ However, in October 2014, the DfE abandoned these plans because of the complexity involved in implementing them. ${ }^{26}$

The Mosques and Imams National Advisory Board (MINAB), a body set up to improve standards in mosques had called for the formal regulation of madrasahs as well. ${ }^{27}$ Prior to this, Siddiqui had recommended that the government establish a national registration scheme for madrasahs, coordinated centrally and monitored by local authorities, to meet their legal obligations as required by the Children Act $1989 .{ }^{28}$

The then Prime Minister through his speech revived the agenda and appears to be determined in making it a reality. Notwithstanding other events and issues, the revelation about some full time Muslim and Jewish schools operating without registration has provided further leverage to argue the case for some form of regulation in the supplementary sector. ${ }^{29}$

\section{Responses from Politicians, Educational groups and various communities}


Following the announcement by David Cameron and the resultant publication of the proposal by the DfE, there was a public debate in reaction to these developments. In this section some of these diverse standpoints, beginning with politicians, academics and other organisations are presented to highlight these concerns and the contentious and problematic nature of the proposed scheme.

\section{Politicians and Educators}

At least 20 MPs had attended the debate about this proposal in Westminster Hall on Wednesday 20 January 2016. There appeared to be cross party agreement between them, with a majority seriously concerned about the impact and implications of the proposed regime. Nick Gibb had announced that more than 10,000 responses had been received which would be considered to develop the policy in more detail. Based on the evidence, he had said that "many settings already have robust measures in place to ensure safety. They may work under umbrella organisations that set high standards, be part of voluntary accreditation schemes or receive support from the local authority. However, that is not universal." Therefore, final proposals, he claimed, would be subject to further discussions with interested parties. ${ }^{30}$ Some MPs thought the proposal had authoritarian measures which would threaten hard-won freedoms and, in particular, inhibit religious freedom. Others felt regulations carried the risk of limiting free speech as they could shut down debate because of the fear, on the part of some youth workers, speaking on issues that might not be mainstream. Others had deep reservations; as it seemed, to them, to be an attack on the big society which the then Prime Minister was trying to create. Moreover, there was anxiety that it might be a disincentive for voluntary organisations to carry on serving their communities. An MP had asked whether the Government had conducted an impact assessment of the financial cost of the registration and assessment process. A few rejected the idea stating there was no point in regulating them as regulation verged on the ridiculous and should be swept away. ${ }^{31}$

Shah argued that the educational, social and economic factors affecting the choices of families who send their children for supplementary education were being ignored in the political hype. ${ }^{32}$ She reasoned that subjecting them to special regimes of inspection could be as counterproductive as other counter-terrorism measures aimed at universities and schools. The government, Shah maintained, needed to address the inequalities and discrimination in society which give people from ethnic minorities different life chances and can result in social divisions and alienation. ${ }^{33}$ On the other hand, Panjwani argued that, in recognising the good work done in supplementary education settings, there was potential that the proposed regulations could become a source to build trust among those sections of Muslim citizens who feel they are being targeted by the Government's approach to extremism. ${ }^{34}$ However, for this potential to be realised, he suggested that the state should clarify that it was not intending to interfere in religious instruction. Therefore, Panjwani recommended that inspectors should receive an induction into the traditions of learning in Muslim communities and the history and status of madrasahs to ensure that the line between conservative religious instruction and extremist discourse is observed. Moreover, where shortcomings were to be found, he endorsed a transparent process of corrective measures. ${ }^{35}$

\section{Christian Responses}

In the proposal, the parameters had been set in such a way that it was thought to affect some activities provided by Christian communities. The Evangelical Alliance, for example, feared 
that Church youth groups, camps, Bible-reading groups, home schooling events or training courses for those under 19, lasting six hours or more per week, would be subject to registration and inspection by Ofsted. ${ }^{36}$ The Alliance had posed important questions to Church leaders and how they thought this proposal would affect their ministries: Would Ofsted regulation limit their activities? Do they consider any tension to exist between 'British Values', 'Extremism' and orthodox biblical teaching? Were they concerned about the cost and burden of these proposals? For teachers, some of whom volunteer their time and energy in faith based educational and youth work, the Evangelical Alliance invited them to consider the implications that this could have for helping out with church activities. They asked: Would the threat of a safeguarding complaint issued against a ministry which they were involved in deter them from volunteering due to the implications for their career? ${ }^{37}$ It had also stated that this was an opportunity for its members to send a powerful message to the government that evangelicals care about the issue and to inform the government about the tremendous work that Christians undertake in the area of supplementary education. These are important questions which similarly could be raised by any faith community including the Muslim community.

The Baptist Union had noted that the matter had been debated in different ways and therefore it was important that anyone wishing to protest or take action does so in response to the document itself and not on hearsay. ${ }^{38}$ The Union offered six ways in which Christians might choose to respond to these proposals. They could oppose by considering that these impose an inappropriate level of state control of religion and oppose them on this basis. It could be elemental as some elements in these proposals are acceptable and others are not, and therefore, representation of specific issues could be made. Third, Christian groups may wish to express concern that the use of safeguarding language in relation to 'extremism' unhelpfully risks confusing two issues that should remain distinct and therefore makes balanced discussion and response more difficult. Christians could also seek exemption and argue that regular core activities should be exempted from these regulations. In other words, they were not to "oppose the legislation itself, but campaign for exemptions for recognised church activities." Importantly, there were concerned about justice. The Union felt it was "hard to read the legislation and not sense that it is written around a particular kind of provision offered by many Muslim communities." As a Gospel, they were "committed to justice for ALL people". Therefore, Churches may be concerned that "these policies could undermine religious freedom for minority groups, and in the interests of justice and liberty make representations on behalf of others." Finally, Churches could argue for self-regulation on the principles that the "proposals could be achieved through voluntary good practice and introduce relevant codes of practice and self-regulation to achieve this, asking for this to be a way forward." 39

The Catholic Education Service (CES) is the education agency of the Catholic Bishops' Conference of England and Wales and, as an agency of the Bishops' Conference, is charged with promoting and securing education on behalf of the bishop. The CES had not opposed the plans, but it had expressed a number of concerns. It broadly supported the regulation of settings "where children are in receipt of intensive education, in so far as it is necessary to protect children's health, safety and welfare." It suggested that there should be "reasonable thresholds to avoid undue and unnecessary burdens" and that the meaning of "intensive education is clearly defined as intensive learning, as opposed to training or instruction that amounts to e.g. sporting, recreational or social activities." 40 
The CES agreed that inspections should be risk based, with Ofsted either acting in response to specific concerns raised by children, parents or the community, or by sampling particular settings, whether by type or region. This, the CES hoped would "avoid undue and unnecessary burdens on both Ofsted and the out of school settings." Nevertheless, whilst the CES had expressed confidence in Ofsted being charged with the investigation of out-of-schools settings, they were "mindful that the first months in which inspections required the evaluation of the promotion of British values revealed that a number of the inspectors were not yet ready for the task." Therefore, in a sensitive area, the CES had suggested that training and moderation would need to be well established in advance of registration. Significantly, it emphasised that it "should also be clear that the remit of an inspection should not extend to doctrinal matters which go beyond that which is demonstrably harmful to children." Furthermore in relation to Ofsted investigations, the CES had considered that it was "important that protections should be included to prevent the regulations being used as a vehicle by campaigning organisations which seek to target religious groups. Vexatious complaints and the use of the system as a means of pursuing political objectives should be prevented." As for the sanctions proposed in the consultation document, the CES had considered them to be appropriate and acceptable. ${ }^{41}$

\section{The National Resource Centre for Supplementary Education (NRCSE)}

The NRCSE is a charity providing quality assurance and training for supplementary schools. Their membership is also open to agencies supporting community-led education. It has over 500 members who are supported in meeting the requirements of the standards of their Code of Practice for Supplementary Schools. Members have access to a nationally recognised quality assurance scheme for the supplementary education sector. The Quality Framework for Supplementary Education uses the Code of Practice to bring together legal requirements and good practice. The Framework determines the levels at which such schools meet the Code of Practice and are awarded at levels Bronze, Silver and Gold. ${ }^{42}$

Based on their experiences, the NRCSE had maintained that greater support to enable more providers of out-of-school-hours activities to improve the quality of their provision would be welcomed. It had also argued that it was difficult to envisage "how 'forcing' community organisations, largely run entirely by volunteers, to be regulated without providing for any form of support or guidance on what they should do in order to meet regulatory requirements could be implemented in a democratic country with a commitment to human rights." 43 Therefore, the NRCSE recommended that all organisations offering out-of-school-hours provision, as well as individuals offering private tuition on a commercial basis, be required to register with a statutory body. They had also recommended that local authorities be mandated to provide access to support on the management of safe learning environments. ${ }^{44}$

\section{Muslim Responses}

The recently formed National Association of Madāris (NAM), whose main aim is to improve and promote excellence in the quality of education offered by madrasahs and to enhance their image accordingly, claimed that Muslim organisations accept that regulation is needed to protect children's welfare. However, it maintained that concerns about radicalisation are misplaced. In relation to the proposals, NAM believed that madrasahs should be registered and regulated to provide educational services, both to protect children and to encourage and maintain high standards of teaching and learning. ${ }^{45}$ 
The Association of Muslim Supplementary Schools (AMSS) was established in 2008 to coordinate the work of Muslim schools and encourage the sharing of best practice in advancing the education of Muslim children in the UK. As a voluntary and non-sectarian organisation with a membership of over 350 Muslim Supplementary schools, which are predominantly madrasahs, its vision is to provide strategies for the empowerment of madrasahs to become centres of excellence in teaching and tarbiyyah. One of its core roles is to represent the interests of Muslim schools within the education sector including in the DfE and other statutory bodies. Part of this role involves participating in consultation forums on policy changes, dissemination of information to their members and making written submission, where appropriate, to consultations on education policy changes, particularly those that impact on Muslim supplementary schools and Islamic education. ${ }^{46}$ The AMSS is at the forefront of providing training and development workshops, regionally and nationally. It provides a Madrasah Improvement Programme and, in partnership with the NRCSE, offers its members access to the NRCSE accredited course. It also provides, what it claims, to be a unique and tailored support programme for experienced teachers looking to gain QTLS status through an accredited Diploma in Education. ${ }^{47}$

In its response to the consultation, it held five conferences in different parts of the country and presented feedback and concerns from the sector. Specifically, it found that "the notion of regulation is scary for many in the sector, mainly due to the perceived targeting of Muslim majority or Muslim-led educational establishments in the UK by OFSTED and Government spokespeople in the recent past." As a result, it stated that many in the sector felt alienated and were sceptical of the proposal. The main reason being that "it is perceived to be a mechanism to "regulate them and what they teach'." Therefore, the AMSS "believe that with this level [of] anxiety among the sector [it] will be counter-productive if a compulsory registration of the sector was mandated as an outcome of the consultation. Therefore, we do not support such action." 48

\section{Humanists $U K(H U K)$ Response}

On the other hand, the HUK welcomed the move of the then Prime Minister to regulate madrasahs, yeshivas, and Sunday schools. The HUK called for "illegal 'faith' schools to be inspected, forced to register, and, if they fail to meet the necessary standards, shut down altogether." ${ }^{49}$ Their actual response to the consultation drew "particular attention to the plight of children within the strictly Orthodox Charedi Jewish community, who despite not being seen as a terror threat, are nonetheless subjected to an appallingly limited, insular, and often abusive education within illegal and unregistered religious schools."

\section{Out-of-school Education Settings: Call for Evidence}

In this section key features of the call for evidence are presented to reveal some of the thresholds to which out-of-school settings would be subject to.

Out-of-school settings are considered to be those providing intensive education, tuition, instruction or training out-of-school. According to the DfE, intensive tuition is anything that entails an individual child, under the age of 19, attending a setting for cumulatively more than between six to eight hours per week, including evenings and weekends. ${ }^{51}$ At the time, the DfE sought to ensure that their threshold was proportionate. However, interestingly, it also stated that this threshold could be varied over time to respond to any emerging or changing risks. 
Significantly, it had declared that this was not "about regulating religion or infringing people's freedom to follow a particular faith or hold particular beliefs." 52

The proposal had stated that any setting falling within the proposed measures would be required to register with their Local Authority and would be eligible for investigation, and if appropriate, intervention where concerns are reported. It had also proposed that Ofsted would undertake the investigative function for out-of-school settings, acting on a risk-based approach in response to concerns raised or on a sample basis, rather than routinely inspecting all providers. ${ }^{53}$ The proposal intended to focus resources on where children receive intensive tuition, instruction or training out-of-school since these are closer in nature to other regulated settings and potentially have greater impact on children, and might pose a greater risk to children. ${ }^{54}$

The key features of the proposed system would include: a requirement on such settings to register; a power for a body to inspect settings to ensure children are being properly safeguarded and a power to impose sanctions for failing to safeguard and promote the welfare of children, which could include barring them from working with children and the closure of premises. It intended to avoid imposing unnecessary burdens on the great number of such settings which are positively enhancing children's education. ${ }^{55}$

\section{Prohibited Activities}

These settings are expected to act in the best interests of children. The proposal claimed that settings would not be required to demonstrate compliance with a set of minimum standards in order to register. ${ }^{56}$ However, concerns raised about any prohibited activities could be reported to the investigative body and inspection could result in action being taken. The proposal identified four specific prohibited activities: failure to adequately ensure the safety of the children in their care; appointing unsuitable staff; accommodating children in unsafe premises and those which threaten their safety or welfare; undesirable teaching, undermining or being incompatible with fundamental British values, or which promotes extremist views and corporal punishment. ${ }^{57}$

\section{Sanctions}

In cases where investigations found evidence of prohibited activities, these would trigger intervention and the application of sanctions as appropriate. These include: powers to stop people from working with children in, or managing, an out-of-school setting and powers to require premises that pose the greatest safeguarding risk to children to cease to be used for specified purposes. ${ }^{58}$

Before analysing the three responses from the selected major Muslim organisations in detail, a brief overview of each organisation is considered and the nature of their response.

\section{Muslim Council of Britain (MCB)}

The MCB is an independent body, established to promote consultation, cooperation and coordination on Muslim affairs in the UK. It is a non-sectarian body working for the common good without interfering in, displacing or isolating any existing Muslim work in the community. It is a broad-based, representative organisation of Muslims in Britain, accommodating and reflecting the variety of social and cultural backgrounds and outlook of 
the community. The MCB is pledged to work for the common good of society as a whole; encouraging individual Muslims and Muslim organisations to play a full and participatory role in public life. ${ }^{59}$

The MCB claimed to have "engaged in a range of consultation on these proposals including sessions in different parts of the country with legal experts, practitioners within education (especially madrasahs) and scholars." ${ }^{60}$ It held a public meeting in London and circulated an online survey to harness the views of their affiliates. Responses to this survey appeared to be limited and were not quantified. Following the survey and the meeting, a sketchy collection of feedback had been presented on its website. It provided the Prevent Strategy as the context, which it emphasised, is considered "toxic by Muslim organisations across the UK." ${ }^{61}$ Following the presentation of the three features of the proposals, it provided a summary of the feedback it received until the publication of these responses. It had stated that the summary would be updated on an ongoing basis. ${ }^{62}$ Their feedback had been presented with reference to the various sections of the consultation. In all, six sections had been created and there did not appear to be a systematic and formal section of recommendations. It was uneasy to decipher and distinguish between the comments received from the survey respondents and those representing and emerging from MCB.

\section{Keep Mosques Independent (KMI)}

KMI campaigned against the regulations through a joint statement from key organisations and individuals in response to the Government's consultation issued by the Northern Council of Mosques (NCM). The statement had invited the general Muslim public of all persuasions to join over 10,000 offline individuals to support their campaign by signing up to either the Joint Statement or the Consultation response or both. Their statement, it had claimed, had been sent to politicians, academics and the media to clearly demonstrate the opposition to such measures. ${ }^{63}$ Prior to this, the NCM had circulated a Friday homily (khutbah) providing information on the Government's proposal to register and monitor mosques/madrasahs under the guise of registering out-of-school settings. ${ }^{64}$ A flyer had also been produced for wider circulation in the community. ${ }^{65}$ Moreover, in January 2016, a press release had been issued. ${ }^{66}$ Consequently, 3761 individual and 552 mosque signatories were amassed from across the country demonstrating the rejection of the Government's proposal. Following preliminary remarks and its fears on government sanctioned religious education, it had claimed that it had a collective duty to represent the concerns of and recommendations from its members from the Islamic religious education sector. KMI welcomed the opportunity to discuss the issues raised in their Joint Statement further with the Government to have meaningful consultation and dialogue. It had made thirteen observations, concerns and recommendations.

\section{British Muslim Forum (BMF)}

Of the three selected responses, the one by BMF seems formal, coherent, mature and thoughtfully considered. The BMF claims to be an independent, national representative umbrella body of 500 national and local member organisations, mosques, madrasahs and charities. It seeks to promote coordination, consultation and cooperation regarding matters affecting the general Muslim community as well as the wider British society in the UK ${ }^{67}$ In response to the proposal, it had stressed the need for greater clarity, fairness and maintaining a correct balance as regards freedom of religion in Great Britain. In the document, the BMF had 
presented its views on matters of governance, children's welfare and countering extremism and had stressed that it was crucial that there [was] faith in [the] consultation process, and that from this process and its findings, there was "further interaction and consultation, rather than quick legislation, in order to avoid further alienation and mistrust." $" 68$

Following a contextual introduction on countering 'extremism' and recognising the achievements of madrasahs, the BMF made four general points on timescale, the perception of the Prevent context, freedom of religion and terminology. Their documents ended with six recommendations and an ending note. ${ }^{69}$ However, the process which led to the creation of the document is absent. Importantly, the BMF drew attention to two significant points: "no single religion can be singled out as being a proponent of extremism, for that would be unjust and historically inaccurate" and that it was important "to recognise that any religious community, and the British Muslim community in particular, should not be treated as a target." Nevertheless, in principle, it agreed that attention was required and counter measures and policies needed to be implemented, nonetheless, "it cannot be the case that hopeful ends justify the means, for if the means are improper, the desired ends may not materialise and further crises emerge that may be contrary to the common good." Thus for the BMF, "the consultation represents the means, and therefore, the government will need to deliberate and carefully consider the responses too." 70

\section{Summative Analysis}

In analysing the responses, the core content was condensed into briefer accumulations of meaning. ${ }^{71}$ This summation enabled to detect where the general direction of each organisation was as well as their general and specific concerns. A bottom-up strategy was utilised wherein a relatively open mind was kept on relevant themes and, through a closer reading of the responses, thematic issues were built. ${ }^{72}$

\section{State Interference in Religious Matters}

All three organisations were concerned about the potential interference of the State directly in religious matters. For instance, the BMF was concerned about the implications for freedom of religion stating: "when a government attempts to scrutinise every aspect of religious life of any community." Still, it admitted that registration and inspection of institutions "may be necessary for the proper functioning of all sections of society." However, these processes, it emphasised, "must be within the framework of religious freedom and take due care to protect the fundamental freedom of religion in this country." Thus, it recommended that a careful balance in this regard is necessary. Similarly, both KMI and MCB presented interference as a major concern. According to MCB, faith teaching in religious institutions "should not be restricted by government interference - such interference is hugely worrying." Moreover, KMI strongly held "onto the view that Mosques/Madrassas and other faith providers including Churches/Sunday Schools and Synagogues/Yeshivas should remain independent to practise and educate within their respective faith without undue Government interference."

\section{Targeting Muslims}

The proposal had used several ambiguous terms which drew criticism. The phrase "intensive teaching" was worrying to the MCB, since it seemed to them "to have been designed to include daily madrasahs and not bible study classes, for example." The MCB argued that "Such choices seem to indicate that the policy is targeting Muslim communities in particular, which seems 
discriminatory." Others felt that "the proposal was looking at education through lens of security." Similarly, KMI believed that the proposition to register was "designed to disproportionately target the Muslim community due to the non-evidential basis of associating Madrassas with radicalisation." In the same vain, such concerns seem to have led the BMF to recommend that any measures taken "cannot be exclusive to Muslims or perceived to be targeted at only Muslims. Otherwise suspicion will increase, and such proposed measures will not inspire community confidence." Moreover, the BMF was anxious that if terminology was not correctly defined, it would open up "ample space for misinterpretation and abuse, which then has a negative impact on communities and the country." Some had worries that the background of the consultation suggested that it was being introduced as part of the Prevent Strategy. ${ }^{73}$

\section{Regulation and Registration}

As regards to the registration, the MCB had recorded that mandatory registration was worrying as it would bring in "extra bureaucracy" which might prevent teaching. Furthermore, it had argued that "religious teaching should not be subject to government interference through a mandatory register" whereas KMI posited that there was "no compelling necessity for regulating a community education sector that has served and flourished independently." In addition, it had also argued that these settings allowed "communities to take responsibility for addressing special and additional educational needs not adequately catered for or provided by the state education system." Therefore, according to KMI, it "would be irresponsible on the part of the government to dampen/ destroy the community spirit, action and ownership that has served the community well." On the other hand, the BMF maintained that "registration itself is not entirely a negative pursuit if it provides for support and capacity building." However, the BMF had emphasised that "the criterion and the threshold for registration" needed to be clarified first. Importantly, the BMF had also suggested that the purpose for which registration was being proposed needed "to be streamlined in order to then suggest the bodies with whom registration took place." The Prevent strategy has been central to all governmental counter extremism efforts, yet, according to the BMF, it is greatly suspected. Therefore, the BMF could not see the reason for such an important step of regulation and governance of education settings still being presented under the Prevent Strategy.

\section{OFSTED}

It was envisaged that the registration requirements would be light-touch. Settings would provide basic details on the proprietors, location, education offered and numbers of children. The settings would be subjected to a Government inspection regime through the Local Authority and/or Ofsted. ${ }^{74}$ All three organisations expressed doubts and reservations regarding the involvement of Ofsted. The MCB, for instance, expressed huge concern "to see OFSTED inspectors within faith institutions asking about how the faith is taught." In addition, they were concerned "about the reliability and capability of OFSTED to perform such inspections." Similarly, KMI argued that since the inspection regime, as with state schools, would inspect the content of its religious teaching against a criteria set by the Government and interpreted by Government inspectors from LA and/or Ofsted, as such, these proposals would clearly depart from "the British tradition not to regulate religious education and worship."

Since the majority of the targeted settings were likely to be from faith traditions in which faith values and ethos play a central role, the BMF had expressed concerned that, "with 
Ofsted's wide-reaching and expanding role, the central essence within these settings will naturally be pushed aside and not given due regard and consideration." Moreover, it had worried that Ofsted would "become the state's arm in scrutinising faith institutions and groups as well as the teaching of faith, without the necessary expertise of understanding the role of faith and keeping within a framework that stands to protect freedom of religion." Though it advocated an independent faith-based approach, the BMF, nevertheless, perhaps as a compromise, recommended that the inspection body, whether Ofsted or otherwise, should include "inspectors from different faith groups, including Muslim inspectors who [would] have the necessary knowledge, knowhow and understanding of these faith settings." However, the MCB preferred that "any inspections should be done within the communities/faith, who understand the nuances they see."

\section{Well-being of Children}

The proposal also intended to ensure that children are accommodated in premises that are safe and do not pose a threat to their safety or welfare. In relation to this, KMI stated that there were many laws and safeguarding measures "to close premises on grounds of health and safety or fire safety concerns or planning violations and also to prosecute those who harm children via the criminal and civil justice system and prohibit them from teaching children again." Therefore, in cases where there were gaps in the law on unsafe premises to teach, then, KMI had suggested that the "Government should consider further legal measures to either prohibit teaching in those premises or closure." That said, for the sake of completeness and clarity, KMI had not supported "the sanctions as set out in para 3.21 of the consultation document to remove teachers or close premises if they are undertaken on grounds of 'extremism'." The BMF had concurred stating that "Criminal matters are subject to the police and prosecution, and health and safety related matters are referred to the Local Authority (fire service, safeguarding, children's services, environmental services, planning and building control, etc.)." The MCB, on the other hand, acknowledged that governance deficiencies were important activities that needed to be improved to ensure "the safety of children, keeping basic records, appointing suitable staff, safe premises, no corporal punishment - are all activities that need to occur," but the MCB did not specify who would be responsible for these. The feedback from their survey acknowledged that appropriate safeguarding was useful and child safety was paramount.

\section{Role of Local Authorities}

Most madrasahs do not operate in a vacuum and many Local Authorities already play a role of some kind in this sector. The BMF had reminded that, as regards education settings within places of worship, they already fell under the Local Authorities as they have a responsibility to seek registration of places of worship and provide planning permission for sites to be used as places of worship and for educational purposes. It had also noted that "Local Authorities may have failed in providing capacity building support to these centres in view of rendering them compliant with legal expectations and standards." Thus, adding to this responsibility of the Local Authority and bringing Ofsted and central government in the process would be "a huge task in terms of registration, inspections and regulations for all out-of-school education settings." Nevertheless, the BMF argued that to promote the welfare of children and quality of practical premises and provision of services, "it may be the case that registration with the Local Authority as a 'place of worship' and/or 'place of out-of-school education' is appropriate, which to some degree already exists." For this to happen, the BMF had suggested that "the 
threshold for registration needs to be quite clear, the registration process itself needs to be very simple so as not to put a strain and burden on settings so as to threaten their very existence, and the expectation from the Local Authority too needs to be made clear." It stressed that registration should not become "an obstacle in the path of positive community endeavour, rather it should be a source of support and professional help with guidelines and resources to enrich these settings." Furthermore, it had emphasised that "the openness and transparency of this process and working partnership needs to be the incentive, if the greater common good is perceived to be the desired outcome." At the same time, KMI called on the Government to recognise "the lengths taken by regional independent advisory bodies which assist religious education in out-of-school settings in putting into place effective safeguarding measures, provide teacher training and developing curriculum to achieve high standards for its children."

\section{All Faiths Independent Body}

All three organisations expressed concerns of various kinds as highlighted above. The MCB had felt there would be "increased bureaucracy and financial burden on voluntary institutions." Moreover, according to the BMF, the involvement of the Local Authority, Ofsted and central government would be a huge undertaking in terms of registration, inspection and regulation for all out-of-school education settings. Fears of Ofsted becoming the State's arm in scrutinising faith institutions as well as the teaching of faith and the protection of freedom of religion had been raised. In view of these concerns, the BMF had suggested that a guidance document for out-of-school education settings towards which centres can build their capacity should be provided. This support and the resources towards this end could come through an independent body. Furthermore, training and support material could be provided as well. The BMF had maintained that a "body that is independent from the state and is well-resourced and funded, with a faith-based approach, will be able to play a far more effective role in capacity building, regulation and inspection of these settings." This body, the BMF had recommended, would have the representation of all faiths and of no faiths within it and whose role would be to oversee this entire process as well as the registration and inspections being carried out. It would oversee measures of providing support and building capacity of mosques and madrasahs. Similarly, where there would be issues of concern over religious education, KMI believed that such concerns were "best addressed by an independent advisory/standard bodies rather than to put in place far reaching powers to regulate all religious education in out-of-school settings through the process of compulsory registrations, inspection and sanction."

\section{'British Values'}

In line with concerns raised about ambiguous terms, the Prevent context, Ofsted and others, the particular reference to 'British values' within prohibited activities had worried the MCB, given the lack of clarity on its definition. On the other hand, the BMF had noted that despite repeated calls to define British values, the closest interpretation is to be found in the advisory document of the DfE, 'Promoting fundamental British values as part of SMSC in schools', which sheds some light on this. Nonetheless, the BMF had felt "it would be appropriate to provide a precise and acceptable definition to such terms with input from faith and no-faith representation, as well as the use of wording that forms part of important legislation." Similarly, KMI was concerned that "orthodox religious ideas and practices will fall foul of any criteria set by Government on how religious education should be taught." It had argued, for example, that "religious concepts related to belief, sacrifice or religious bonds of unity as well as religious practices" of various kinds were "likely to fail any educational criteria set by the 
Government." KMI had posited that this was because it was apparent that the Government had "adopted an 'aggressive secular' interpretation of the vaguely defined term 'British values' and the equally vague benchmark which is found in Government reports that some 'failing schools' 'do not prepare children for modern British life."”

\section{Discussion}

The Government's position in relation to its proposal being part of the strategy to counter 'extremism' is unambiguous. Thus, the responses to the proposal had to be viewed in light of the opposition of some Muslim communities against the unfair and discriminatory policies represented by the Counter-Extremism Strategy and Prevent Strategy. It has been argued that theories about radicalisation and extremism are doubtful, unworkable, controversial and counterproductive. ${ }^{75}$ Moreover, it is also believed that the definition of 'extremism' and 'radicalisation', which lie at the heart of this regulation, is open to abuse due to its vagueness and lack of objective definition. ${ }^{76}$ Thus, should the policy become a reality, as with other educational policies, the results will be far reaching for madrasah education in the UK.

During the consultation period, most Muslim organisations and a large number of individuals from a cross section of communities and some Christian organisations had feared that the nature of the proposal was such that it would target the Muslim community and exempt many other faith based out-of-school settings. Having said this, in the document, the term madrasah had not featured. However, the context and its references to the Prevent Strategy left no doubt for Panjwani that its primary concern was with Muslim supplementary education settings. ${ }^{77}$ Even-though the then Prime Minister had mentioned three religious institutions specifically, nevertheless, Shah felt that the target was primarily Muslim madrasahs. ${ }^{78}$ These concerns were compounded by an announcement made by Nicky Morgan and the confirmation by Nick Gibb that Sunday schools would be exempted.

The proposal had identified four specific prohibited activities. ${ }^{79}$ Of these, the requirement that teaching in these settings should not undermine or be incompatible with fundamental 'British values' remains contentious. Then there is the question of the meaning of 'undesirable teaching' which requires transparency so that its interpretation is not open to abuse and individual judgements. It should be noted, however, that madrasahs exist for teaching, respect, service, generosity, honesty, justice, caring, rule of law, love and other morals and values. ${ }^{80}$ Nevertheless, considerable disquiet exists among many Muslims, Christians, other faith communities and politicians about 'British values' as they are ill-defined and vague. ${ }^{81}$ In Parliament, concerns had been raised about Ofsted deciding whether doctrinal teachings met the 'British values' test. Some Christian groups, were "terrified" because, for the first time, Ofsted would decide whether church teachings were compatible with, and did not undermine 'British values'. It had been argued that a regime constructed on 'British values' and undesirable teaching would be "ripe for subjective, exaggerated and politically-motivated complaints, especially against religious groups." 82 Moreover, it had also been argued that making religious instruction subject to a state-controlled authoritative version of vaguely defined British values was deeply problematic. ${ }^{83}$

It is, therefore, important to note the clarification which had been provided by Nick Gibb, who had said, "Out-of-school settings will not have the same obligations as schools actively to promote fundamental British values. Although out-of-school settings of all types can, and do, impart positive values to children, they are not the main providers of children's education, and 
it is certainly not the state's role to prescribe what they should teach, just as we are not seeking to prescribe other aspects of how they operate." He had gone further to reassure Christian communities that "Sunday schools will not be under any requirement to teach any other religions." 84

The other major concern related to the interference of the Government in targeting religious and faith matters which was deemed to erode civil and religious liberties. It had been feared that Government sanctioned faith education would "lead to alienated faith communities and unduly encroaches on the legitimate right of faith providers to teach their children their faith." ${ }^{\circ 5}$ It was also mentioned that, in the UK, for some time there has been a tradition of not interfering in doctrinal and theological matters and, so modifying such a tradition would not only be divisive but might open doors for further encroachment. However, both the consultation and Nick Gibb apparently were clear that the Government had "no intention of seeking to regulate religion or to interfere in parents' rights to teach children about their faith and heritage." Since, the protection of "religious liberty is a fundamental principle." 86

That said, the well-being, safety and safeguarding; physical, spiritual and social, of children is of utmost importance and, to that extent, it seems practical for Muslims in Britain to recognise the attention of the Government in advancing the improvement of governance, transparency and facilities, in the hope that they may truly become beacons of guidance and tarbiyyah. The responses surveyed and other responses reviewed, among the Muslim communities, apparently demonstrate considerable unanimity on matters related to health and safety, child protection and safeguarding issues. It is also the case that most organisations recognise the role that registration can play in further enhancing these matters. The way forward, it appears, is to divorce it from central government control and the anti-terrorism agenda and bring it closer to an independent body or within the parameters of Local Authorities.

The madrasah sector in the UK has been undergoing changes for many years. Thus a call to this effect is a not a new call. Indeed, there are issues with management, resources, and some teachers have meted out corporal punishment. ${ }^{87}$ However, in the absence of strong evidence linking madrasahs to extremism and viewing them through the lens of security and terrorism is unfortunate. ${ }^{88}$ As far as madrasahs in the UK are concerned many would refute the direct link with terrorism as baseless.

In addition, research has challenged many stereotypes surrounding the ways into violent extremism. Travis reported that the sophisticated analysis of MI5, based on hundreds of case studies by the security service, found that "far from being religious zealots, a large number of those involved in terrorism do not practise their faith regularly. Many lack religious literacy and could actually be regarded as religious novices. Very few have been brought up in strongly religious households." Importantly, the MI5 stated that "there is evidence that a wellestablished religious identity actually protects against violent radicalisation." 89 The exclusive targeting of madrasahs is likely to create a sense of unfairness among many Muslims. The emphasis on the inclusion of all supplementary schools, Muslims or otherwise, has the potential of showing a greater degree of coherence in policy.

The then Prime Minister reassured the public that there was nothing wrong with children learning about their faith in madrasahs, Sunday Schools or Jewish yeshivas. Thus, it is significant to acknowledge the multifaceted contributions that this diverse sector makes across the UK in a wide variety of ways towards the religious, personal, social, moral, cultural, 
emotional and spiritual development of children and young people in building a stronger nation. Thus, madrasahs in the UK should be conceived as 'problem' solvers rather than makers.

\section{NOTES}

1 Michael Wilkinson, "David Cameron: A greater Britain with Conservatives, not with terrorist-sympathising Jeremy Corbyn- as it happened", The Telegraph, 07 October 2015, available online, http://www.telegraph.co.uk/news/politics/david-cameron/11916178/davidcameron-speech-conservative-conference-live.html (accessed 28 April 2016)

${ }^{2}$ Mikey Smith, "David Cameron's full speech to Conservative Party conference - read and watch it here", The Mirror, 07 October 2015, available online, http://www.mirror.co.uk/news/uk-news/david-camerons-full-speech-conservative-6589711 (accessed 28 April 2016).

${ }^{3}$ HM Government, Counter-Terrorism Strategy, Cm 9184, London: Home Office, 2015.

${ }^{4}$ Ibid. p.21.

${ }^{5}$ Ibid. p.26-27.

${ }^{6}$ DfE, Out-of-school education settings: registration and inspection, London: Department for Education, 2015.

${ }^{7}$ Hansard, "Out-of-school Education Settings", Westminster Hall, 20 January 2016a, Column $589 \mathrm{WH}, \quad 590 \mathrm{WH}$ and $591 \mathrm{WH}, \quad$ available http://www.publications.parliament.uk/pa/cm201516/cmhansrd/cm160120/halltext/160120h0 $\underline{001 . h t m \# 16012030000001}$ (accessed 22 April 2016).

${ }^{8}$ Hansard, “Oral Answers to Questions Education”, 25 January 2016b, Column 24, available online,

http://www.publications.parliament.uk/pa/cm201516/cmhansrd/cm160125/debtext/160125$\underline{0001 . h t m}$ (accessed 22 April 2016).

${ }^{9}$ Imran Mogra, "Moving Forward with Makātib: The Role of Reformative Sanctions", Muslim Educational Quarterly, Vol. 22, Nos. 3\&4, Spring/Summer, 2005, pp. 52-64. Ghayasuddin Siddiqui, "Child Protection in Faith-based Environments: A guideline report", London: The Muslim Parliament of Great Britain, 2006. Ishtiaq Ahmed and Azra Riasat, Children do matter. Bradford: Council for Mosques Bradford, 2013. Jonathan Scourfield, Sophie Gilliat-Ray, Asma Khan and Sameh Otri, Muslim Childhood, Oxford: Oxford University Press, 2013.

${ }^{10}$ Yusef Waghid, "Education and madrassahs in South Africa: on preventing the possibility of extremism", British Journal of Religious Education, Vol. 31, No. 2, 2009, pp. 117-128. Myriam Cherti, Alex Glennie and Laura Bradley, 'Madrassas' in the British media, London: Institute for Public Policy Research, 2011. John Ryan, Kathryn Last, and Jayne Woodbury, "Independent evaluation of the ASDAN Islam and citizenship short course", Project Report. ASDAN/Paul Hamlin Foundation, 2012. Intan Azura Mokhtar, "Madrasahs in Singapore: Bridging between their Roles, Relevance and Resources", Journal of Muslim Minority Affairs, Vol. 30, No. 1, 2010, pp. 111-125.

${ }^{11}$ Ofsted, "Handbook for additional inspections of independent schools", Manchester: Ofsted, 2015. 
${ }^{12}$ Association of Muslim Schools, The AMS Brochure, Birmingham: AMS, n.d.

${ }^{13}$ Gerald Grace, "Educational studies and faith-based schooling: moving from prejudice to evidence-based argument", British Journal of Educational Studies, Vol. 51, No, 2, 2003, pp. 149-167. Ian Schagen and Sandie Schagen, "The impact of faith schools on pupil performance", in Faith Schools: Consensus or Conflict? Eds. Roy Gardner, Jo. Cairns and Denis Lawton, London: Routledge, 2005, pp. 202-212. John Fling, "Faith schools, multiculturalism and community cohesion: Muslim and Roman Catholic state schools in England and Scotland", Policy \& Politics, Vol. 35, No. 2, 2007, pp. 251-68.

${ }^{14}$ Myriam Cherti, Alex Glennie and Laura Bradley, 'Madrassas' in the British media, op.cit.

${ }^{15}$ Cf. Myriam Cherti, Alex Glennie and Laura Bradley, 'Madrassas' in the British media, op.cit.

${ }^{16}$ Imran Mogra, "Makātib in Britain" A Review of Trends and Some Suggestion for Policy", Muslim Educational Quarterly, Vol. 21, Nos. 3\&4, Spring/Summer, 2004, pp. 19-27.

${ }^{17}$ Ofsted, "Handbook for additional inspections of independent schools", op.cit.

${ }^{18}$ Myriam Cherti, Alex Glennie and Laura Bradley, 'Madrassas' in the British media, op.cit.

${ }^{19}$ Myriam Cherti, Alex Glennie and Laura Bradley, 'Madrassas' in the British media, op.cit.

${ }^{20}$ Gary Eason, "Do independent school regulations leave loopholes?" 26 November 2009, available online, http://news.bbc.co.uk/1/hi/education/8381473.stm (accessed 29 April 2016).

${ }^{21}$ Uvanney Maylor, Katie Glass, Tozun Issa, Kuyok Abol Kuyok, Sarah Minty, Anthea Rose, Alistair Ross, Emily Tanner, Steven Finch, Natalie Low, Eleanor Taylor and Sarah Tipping, Susan Purdon, "Impact Of Supplementary Schools On Pupils' Attainment: An Investigation Into What Factors Contribute To Educational Improvements", DCSF research report DCSFRR210, London: London Metropolitan University, 2010.

${ }^{22}$ Myriam Cherti, Alex Glennie and Laura Bradley, 'Madrassas' in the British media, op.cit.

${ }^{23}$ John Ryan, Kathryn Last, and Jayne Woodbury, "Independent evaluation of the ASDAN Islam and citizenship short course", op.cit.

${ }^{24}$ HM Government, "Tackling extremism in the UK December 2013: Report from the Prime Minister's Task Force on Tackling Radicalisation and Extremism”, London: HM Government, 2013.

${ }^{25}$ Teresa May, “Theresa May's letter to Michael Gove in full”, 04 June 2014, available online, http://www.theguardian.com/politics/2014/jun/04/theresa-may-letter-michael-gove-in-full (accessed 24 April 2016).

${ }^{26}$ BBC "Code of practice for religious schools shelved", 23 October 2014, available online, http://www.bbc.co.uk/news/uk-29729669 (accessed 24 April 2016).

${ }^{27}$ Shabnam Mahmood, "Bradford madrassas leading reforms to 'safeguard Muslim students'", 2 April 2013, available online, http://www.bbc.co.uk/news/uk-21975225 (accessed 23 April 2016).

${ }^{28}$ Ghayasuddin Siddiqui, Child Protection in Faith-based Environments: A guideline report, op.cit. 
${ }^{29}$ Fran Abrams, "Why are Orthodox Jewish religious schools unregulated?" Guardian, 11 August 2015, available online, http://www.theguardian.com/education/2015/aug/11/orthodoxjewish-religious-schools-unregulated-london-yeshiva (accessed 24 April 2016).

${ }^{30}$ Hansard, Out-of-school Education Settings, Westminster Hall, 20 January 2016a, op.cit.

${ }^{31}$ Ibid.

${ }^{32}$ Seeda Shah, "Clampdown on madrassas misses the point of why parents send children for extra study", The Conversation, 15 October 2015, available online, https://theconversation.com/clampdown-on-madrassas-misses-the-point-of-why-parentssend-children-for-extra-study-49031 (accessed 12 April 2016).

${ }^{33}$ Ibid.

${ }^{34}$ Farid Panjwani, "As Britain plans to regulate madrasas, let's understand their history", 16 December 2015 available online, https://theconversation.com/as-britain-plans-to-regulatemadrasas-lets-understand-their-history-52094 (accessed 28 April 2016).

${ }^{35}$ Ibid.

36 Evangelical Alliance, "Respond to the government's consultation on out-of-school education", 07 December 2015, available online, http://www.eauk.org/currentaffairs/politics/evangelical-alliance-calls-members-to-respond-to-extremism-consultation.cfm (accessed 25 April 2016).

${ }^{37}$ Ibid.

${ }^{38}$ Baptist Union of Great Britain, "Responding to the Out of School Education Service Call for Evidence", available online, http://www.baptist.org.uk/Articles/456040/Out_of_School.aspx, (accessed 29 April 2016).

${ }^{39}$ Ibid.

${ }^{40} \mathrm{CES}$, “Consultation Response - Out of school education settings-call for evidence”, London: Catholic Education Service, 2016.

${ }^{41}$ Ibid.

${ }^{42}$ The National Resource Centre for Supplementary Education, "Supplementary Education", 2016, available online, http://www.supplementaryeducation.org.uk/supplementary-educationthe-nrc/ (accessed 21 April 2016).

${ }^{43}$ Pascale Vassie, "Inspection of supplementary schools?" 21 October 2015, available online, http://www.supplementaryeducation.org.uk/inspection-of-supplementary-schools/ (accessed 21 April 16).

${ }^{44}$ Ibid.

${ }^{45}$ National Association of Madāris: Providing advice, information and guidance for: teacher training, professional management and governance of the mosque Quran Schools, 2015, available online, http://namadaris.com/wp-content/uploads/2015/12/National-Association-ofMadraris.pdf (accessed 21 April 2016).

${ }^{46}$ Association of Muslim Supplementary Schools, "The Association of Muslim Supplementary Schools", available online, http://amss.org.uk/Our\%20Mission.html (accessed 21 April 2016).

${ }^{47}$ Ibid. 
48 AMSS, "AMSS Response to Consultation - Out-of-school education settings: call for evidence", 2016a, personal communication, 13 January 2016.

${ }^{49}$ British Humanist Association, “BHA repeats calls for crackdown on illegal 'faith' schools in response to Government consultation", 14 January 2016, available online, https://humanism.org.uk/2016/01/14/44704/ (accessed 25 April 2016).

${ }^{50}$ Ibid.

${ }^{51}$ DfE, Out-of-school education settings: registration and inspection, op.cit.

${ }^{52}$ Ibid.

${ }^{53}$ Ibid.

${ }^{54}$ Ibid.

${ }^{55}$ Ibid.

${ }^{56}$ Ibid.

${ }^{57}$ Ibid.

${ }^{58}$ Ibid.

${ }^{59} \mathrm{MCB}$, “About MCB”, available online, http://www.mcb.org.uk/about-mcb/ (accessed 24 April 2016).

${ }^{60} \mathrm{MCB}$, "Feedback received on Government's proposal for Out-of-school education settings, 2016a, available online, http://www.mcb.org.uk/feedback-received-on-governments-proposalfor-out-of-school-education-settings/ (accessed 24 April 2016).

${ }^{61} \mathrm{MCB}$, "Feedback received on Government's proposal for Out-of-school education settings, 2016a, op.cit.

${ }^{62}$ Ibid.

${ }^{63}$ Keep Mosques Independent, "This is a Joint Statement of Key Organisations and Individuals in response to the Government's consultation on 'Out of school education setting: call for evidence",, 2015, available online, http://keepmosquesindependent.org/this-is-a-jointstatement-of-key-organisations-and-individuals-in-response-to-the-governmentsconsultation-on-out-of-school-education-settings/ (accessed 26 April 2016).

${ }^{64}$ Keep Mosques Independent, "Khutba - Keep Mosques Independent”, 23 December 2015a, available online, http://keepmosquesindependent.org/2015/12/23/khutba-keep-mosquesindependent/ (accessed 26 April 2016).

${ }^{65}$ Keep Mosques Independent, “Keep Mosques Independent - Flyer", 24 December 2015b, available online, http://keepmosquesindependent.org/2015/12/24/keep-mosques-independentflyer/ (Accessed on 26 April 2016).

${ }^{66}$ Sean Coughlan, “Mosques oppose madrassa registration”, 7 January 2016, available online, http://www.bbc.co.uk/news/education-35252469 (accessed 26 April 2016).

${ }^{67}$ British Muslim Forum, “The British Muslim Forum calls for an independent commission on out-of-school education settings", 5 January 2016, available online, http://www.britishmuslimforum.co.uk/2016/01/05/the-british-muslim-forum-calls-for-anindependent-commission-on-out-of-school-education-settings (accessed 26 April 2016). 
${ }^{68}$ Ibid.

${ }^{69}$ Ibid.

${ }^{70}$ Ibid.

${ }^{71}$ Johnny Saldaña, Thinking Qualitatively: methods of mind. London: SAGE, 2015.

${ }^{72}$ Brian Alleyne, Narrative Networks, London: SAGE, 2015.

${ }^{73}$ HM Government, Prevent Strategy, London: HMSO, 2011.

${ }^{74} \mathrm{DfE}$, Out-of-school education settings: registration and inspection, op.cit.

${ }^{75}$ Linda Woodhead 'Drain the swamps or concentrate on the crocodiles?' Westminster Faith Debates, 05 June 2014. Arun Kundnani, The Muslims are Coming! Islamophobia, extremism and the domestic war on terror, London: Verso, 2014. Arun Kindnani, A Decade Lost: Rethinking radicalisation and extremism. London: Claystone, 2014, available online, http://www.claystone.org.uk/wp-content/uploads/2015/01/Claystone-rethinking-

radicalisation.pdf (accessed 10 May 2016). Miqdad Versi, Response to the Counter-Terrorism and Security Bill. London: Muslim Council of Britain. 06 June 2015, available online, www. mcb.org.uk/wp-content/uploads/2015/01/Response-to-the-Counter-Terrorism-and-SecurityBill.pdf (accessed 10 May 2016).

${ }^{76}$ Keep Mosques Independent, 2015, op.cit.

${ }^{77}$ Farid Panjwani, “As Britain plans to regulate madrasas, let's understand their history”, op.cit.

${ }^{78}$ Seeda Shah, "Clampdown on madrassas misses the point of why parents send children for extra study", op.cit.

${ }^{79}$ DfE, Out-of-school education settings: registration and inspection, op.cit.

${ }^{80}$ Imran Mogra, "Moral Education in the makātib of Britain: a review of curriculum materials", Journal of Moral Education, Vol. 36, No. 3, 2007, pp. 387-398.

${ }^{81}$ James Arthur, "Extremism and Neo-Liberal Education Policy: A Contextual Critique of the Trojan Horse Affair in Birmingham Schools", op.cit.

${ }^{82}$ Hansard, Out-of-school Education Settings, Westminster Hall, 20 January 2016a, op.cit.

${ }^{83}$ Ibid.

${ }^{84}$ Ibid.

${ }^{85}$ Keep Mosques Independent, 2015, op. cit.

${ }^{86}$ Hansard, Out-of-school Education Settings, Westminster Hall, 20 January 2016a, op.cit.

87 Shabnam Mahmood, "Bradford madrassas leading reforms to 'safeguard Muslim students,", op.cit.

${ }^{88}$ Myriam Cherti, Alex Glennie and Laura Bradley, 'Madrassas' in the British media, op. cit.

${ }^{89}$ Alan Travis, "MI5 report challenges views on terrorism in Britain", The Guardian, 20 August 2008, available online, http://www.theguardian.com/uk/2008/aug/20/uksecurity.terrorism1 (accessed 11 May 2016). 